\title{
Deicer Impacts on Pavement Materials: Introduction and Recent Developments
}

\author{
Xianming Shi ${ }^{1,2, *}$, Michelle Akin ${ }^{1}$, Tongyan Pan $^{1}$, Laura Fay ${ }^{1}$, Yajun Liu ${ }^{1}$ and Zhengxian Yang ${ }^{1}$ \\ ${ }^{1}$ Corrosion and Sustainable Infrastructure Laboratory, Western Transportation Institute, PO Box 174250, College of \\ Engineering, Montana State University, Bozeman, MT 59717-4250, USA \\ ${ }^{2}$ Civil Engineering Department, 205 Cobleigh Hall, Montana State University, Bozeman, MT 59717-2220, USA
}

\begin{abstract}
A review of the impacts of deicers used in winter maintenance practices of Portland cement concrete and asphalt concrete roadways and airport pavements is presented. Traditional and relatively new deicers are incorporated in this review, including sodium chloride, magnesium chloride, calcium chloride, calcium magnesium acetate, potassium acetate, potassium formate, sodium acetate, and sodium formate. The detrimental effects of deicers on Portland cement concrete exist through three main pathways: 1) physical deterioration such as "salt scaling"; 2) chemical reactions between deicers and cement paste (a cation-oriented process, especially in the presence of magnesium chloride and calcium chloride); and 3) deicers aggrevating aggregate-cement reactions (such as the anion-oriented process in the case of chlorides, acetates, and formates affecting alkali-silica reactivity and the cation-oriented process in the case of calcium chloride and magnesium chloride affecting alkali-carbonate reactivity). The deicer impacts on asphalt concrete pavements had been relatively mild until acetate- and formate-based deicers were introduced in recent years. The damaging mechanism seems to be a combination of chemical reactions, emulsifications and distillations, as well as the generation of additional stress in the asphalt concrete.
\end{abstract}

\section{INTRODUCTION}

In cold-climate regions, snow and ice control operations are crucial to maintaining highways that endure cold and snowy weather. The growing use of deicers has raised concerns about their effects on motor vehicles, transportation infrastructure, and the environment. The deleterious effect of chloride-based deicers on reinforcing steel bar (rebar) in concrete structures is well known [1]. Deicers may also pose detrimental effects on concrete infrastructure through their reactions with cement paste and/or aggregates and thus reduce concrete integrity and strength, which in turn may foster the ingress of moisture, oxygen and other aggressive agents onto the rebar surface and promote rebar corrosion.

This literature review presents a synthesis of the impacts of common deicers on cement and asphalt pavements, respectively, detailing the various mechanisms found to cause deterioration. The following sections document the impacts sodium chloride $(\mathrm{NaCl})$, calcium chloride $\left(\mathrm{CaCl}_{2}\right)$ and magnesium chloride $\left(\mathrm{MgCl}_{2}\right)$ have on pavement materials, compared with those of alternative deicers such as calcium magnesium acetate (CMA), potassium acetate (KAc), potassium formate $(\mathrm{KFm})$, sodium acetate $(\mathrm{NaAc})$, and sodium formate (NaFm).

\section{DEICER EFFECTS ON PORTLAND CEMENT CONCRETE}

Previous studies on deicer/concrete interactions used mostly concentrated deicer solutions. A Transportation

\footnotetext{
*Address correspondence to this author at the Civil Engineering Department, 205 Cobleigh Hall, Montana State University, Bozeman, MT 597172220, USA; Tel: 406-994-6486; Fax: 406-994-1697;

E-mail: xianming_s@coe.montana.edu
}

Pooled Fund study [2] investigated the effects of concentrated brines of $\mathrm{NaCl}, \mathrm{CaCl}_{2}, \mathrm{MgCl}_{2}$ and $\mathrm{CMA}$ on Portland cement concrete (PCC) and concluded that both physical and chemical interactions occur within concrete when it is exposed to freeze/thaw conditions and deicers. Based on the ASTM C 666 freeze/thaw test results, concrete prisms of 10 $\mathrm{cm}$ diameter by $5 \mathrm{~cm}$ height subjected to 300 freezing/thawing cycles in $14 \% \mathrm{MgCl}_{2}$ and $15 \% \mathrm{CaCl}_{2}$ reported considerable expansion $(0.17 \%$ and $0.18 \%$ length change, respectively), mass change $(3.5 \%$ and $-3.5 \%$, respectively) and loss in the dynamic modulus of elasticity $(50 \%$ and $40 \%$, respectively). In contrast, those exposed to $18 \% \mathrm{NaCl}$ did not expand more than $0.04 \%$ and reported $0.5 \%$ mass gain and approximately $5 \%$ loss in the dynamic modulus of elasticity. Significant evidence existed that $\mathrm{MgCl}_{2}$ and $\mathrm{CaCl}_{2}$ chemically reacted with hardened cement paste, as indicated by the dissolution of the cement paste and formation of expansive oxychloride phases. These mechanisms were assumed responsible for the observed expansive cracking, increased permeability, and significant loss in compressive strength of the concrete [2]. Exposure to $\mathrm{NaCl}$, however, did not result in noticeable chemical interaction or related distress in concrete mortar or concrete [2].

A recent study [3] in our laboratory investigated the effects of diluted deicers on PCC, assuming a 100-to-3 dilution ratio for all liquid and solid deicers. Based on the gravimetric and macroscopic observations of freeze-thaw specimens following the SHRP H205.8 laboratory test, de-ionized water, the CMA solid deicer, and the $\mathrm{MgCl}_{2}$ liquid deicer were benign to the PCC durability, whereas KFm and the NaAc/ $\mathrm{NaFm}$ blend deicers showed moderate amount of weight loss and noticeable deterioration of the concrete. $\mathrm{NaCl}$, the $\mathrm{NaCl}$ based deicer, and the KAc-based deicer were the most dele- 
terious to the concrete. In addition to exacerbating physical distresses, each investigated chemical or diluted deicer chemically reacted with some of the cement hydrates and formed new products in the pores and cracks. Such physiochemical changes of the cement paste induced by the deicers pose various levels of risks for the concrete durability.

Yet another laboratory study investigated the effects of both diluted and concentrated deicers on PCC. Concrete specimens were exposed to weekly cycles of wetting and drying in distilled water and in solutions of $\mathrm{NaCl}, \mathrm{CaCl}_{2}$, $\mathrm{MgCl}_{2}$, and CMA with either a 6.04 molal ion concentration (equivalent to a $15 \%$ solution of $\mathrm{NaCl}$ ), or a 1.06 molal ion concentration (equivalent to a $3 \%$ solution of $\mathrm{NaCl}$ ), for periods of up to 95 weeks. At lower concentrations, $\mathrm{NaCl}$ and $\mathrm{CaCl}_{2}$ showed a relatively small negative impact on the properties of concrete, whereas $\mathrm{MgCl}_{2}$ and CMA caused measurable damage to concrete. At high concentrations, $\mathrm{NaCl}$ showed a greater but still relatively small negative effect, whereas $\mathrm{CaCl}_{2}, \mathrm{MgCl}_{2}$ and $\mathrm{CMA}$ caused significant loss of material and a reduction in stiffness and strength of the concrete [4].

In addition to chlorides, the detrimental effects of CMA on PCC have also been confirmed. In a recent laboratory study, cement mortar samples (water to cement ratio $(\mathrm{w} / \mathrm{c})=0.485)$ were reported to lose cohesiveness and disintegrate completely after 30-day exposure to 28\% CMA solution at room temperature, and the formation of calcium acetate hydrate phases were confirmed by X-ray diffraction results [2]. In another laboratory study [5], eight-month continuous exposure of good-quality concrete $(\mathrm{w} / \mathrm{c}=0.45$ and airentrained) to concentrated CMA solutions $(25 \%)$ caused a significant decrease in load capacity, mass loss and severe visual degradation of the concrete. The use of $40 \%$ blast furnace slag along with a Portland clinker was found effective in mitigating such impacts of CMA [5]. The deleterious effects of CMA were also reported in earlier studies [6, 7], involving a delamination process of the cement matrix likely associated with leaching of the calcium hydroxide.

In light of these studies, it appears that deicers may pose a risk for the durability of PCC structures and pavements through three main pathways: 1) physical deterioration of the concrete through such effects as salt scaling; 2) chemical reactions between deicers and concrete; and 3) deicers aggravating aggregate-cement reactions.

\subsection{Deicer Scaling - A Physical Process}

Physical mechanisms of attack by deicers can lead to damage of PCC in the common forms of scaling, map cracking, or paste disintegration [2]. Scaling refers to the local peeling of the hardened concrete surface, often as a result of cyclic freezing and thawing [8]. Scaling can occur on concrete surfaces independent of deicer application, as the aqueous solution in the concrete pores near the surface freezes and thaws due to temperature fluctuations. Freezing of water in saturated concrete exerts tremendous expansive forces that consequently lead to scaling off of concrete surfaces, especially when the concrete surface is not adequately protected with entrained air.

Many research studies have shown that chloride-based deicing salts can exacerbate the scaling problem as concrete experiences freeze/thaw cycles. Moisture tends to move to- ward zones with higher salt concentrations via osmosis. Accordingly, the osmotic pressure adds to the normal hydraulic pressure if salts are present in the pore solution, which increases the risk for physical deterioration of concrete. In addition, the application of deicing salts to pavements increases the rate of cooling, which increases the number of freeze/thaw cycles and thus the risk for freeze/thaw deterioration. However, the presence of deicers can be beneficial as it widens the temperature range in which phase transitions occur. These opposing effects define the physical distress in concrete caused by deicers, and a pioneering laboratory study revealed the worst conditions at a low deicer concentration $(5 \% \mathrm{NaCl})$ and optimum conditions at a moderately high concentration $(13 \% \mathrm{NaCl})$ [9]. Another study suggested that concrete containing relatively high concentrations of dissolved salts can provide better resistance to scaling than concrete with plain water in its pores [10].

The scaling of concrete in the presence of deicers, referred to as "salt scaling" has been recognized as the main cause of frost-related concrete deterioration, and has been found closely related to concrete quality (e.g., air entrainment level), weather conditions, and the number of freeze/thaw cycles [11-14]. Concrete damage from salt scaling was found to be significantly dependent on the salt type (sodium, potassium, magnesium or calcium chloride) and salts containing potassium seemed to cause more scaling damage for unknown reasons [15].

KAc was reported to cause minor scaling associated with alkali carbonation of the surface layer of concrete [16]. Recently, however, the treatment of PCC with sodium acetate solutions was claimed to be a promising technology to grow crystals inside the pores to reduce water penetration into concrete and thus extend the service life of concrete [17]. Such beneficial effect was demonstrated in the treatment of a poor-quality concrete ( $\mathrm{w} / \mathrm{c}=0.65$ and non-air-entrained).

Early research argued that the best protection against "salt scaling" would be reduction of porosity [9]. It is now generally believed that the use of properly cured, airentrained Portland cement concrete would prevent physical damage by the freeze/thaw cycles. For instance, high-quality concrete with 5-7\% entrained air has been found more resistant to freeze/thaw cycles and scaling [18]. Entrained air provides spaces within the concrete mass for expanding water to move into, thereby reducing the potential stress and associated deterioration. For an air-entrained concrete, the spacing factor seems to be its key air void characteristic to allow sufficient resistance to salt scaling [19]. It should be noted that air entrainment only slows the freeze-thaw process instead of preventing it [10].

The use of supplementary cementitious materials, particularly fly ash, has been widely reported to have detrimental effects on the scaling resistance of properly air-entrained concrete, as it tends to refine porosity and increase the nonevaporable water content [20]. One study suggested that the key was to allow sufficient time for high-volume fly ash concrete to develop strength before subjecting it to salt scaling [21]. In contrast, the use of some cementitious material may improve the resistance of mortars and concretes to the combined action of frost and deicer, as in the case of a magnesium phosphate cement-based binder prepared by mixing 
magnesium oxide $(\mathrm{MgO})$ with mono-ammonium phosphate, borax and fly ash [22].

\subsection{Reactions between Deicers and Concrete - A Cation- Oriented Chemical Process}

Chemical mechanisms of attack by deicers can lead to damage of PCC in the common forms of map cracking, paste disintegration, internal microcracking, strength loss, mass gain, and expansion. The following strategies were recommended to mitigate the deleterious effects of deicers: 1) use less deicing chemicals; 2) use $\mathrm{NaCl}$ brines wherever possible, 3) use concrete sealants (e.g., siloxanes and silanes) and concrete mixtures with supplementary cementitious materials (e.g., ground granulated blast furnace slag and coal fly ash) [2].

\section{Sodium Chloride ( $\mathrm{NaCl})$}

Sodium chloride $(\mathrm{NaCl})$ remains the principal road deicer in use despite its well-known corrosive effects on metals. It has a eutectic point of $-23^{\circ} \mathrm{C}$, good ice-melting rates at low temperatures and, above all, is relatively inexpensive. Generally, salt scaling appears to be limited to the concrete surface when $\mathrm{NaCl}$ is used. Unless reactive aggregates are included in thick concrete structures such as bridge decks, $\mathrm{NaCl}$, when used as a deicer, does not cause serious deterioration in concrete except for the surface distress caused by the physical mechanism of scaling. Long-term use of $\mathrm{NaCl}$ does not result in strength loss in the cement paste matrix via chemical mechanisms except for the slow process of accelerating alkali-silica reaction.

While $\mathrm{NaCl}$ itself may be innocent, deicers originating from mines (rock salt, as opposed to solar salt) may contain significant traces of calcium sulfate. Research by Pitt et al. [23] showed that even low levels of $\mathrm{CaSO}_{4}$ can damage mortar, especially in combination with freezing and thawing cycles, due to pore filling by possibly Friedel's salt and ettringite. To minimize such damage, changes in mix design or treating joints and cracks with silane sealers can be effective, while establishing restrictions on $\mathrm{CaSO}_{4}$ limits in rock salt used for deicing may be difficult.

\section{Magnesium Chloride $\left(\mathrm{MgCl}_{2}\right)$}

Numerous research studies have shown that $\mathrm{MgCl}_{2}$, when used as a deicer, causes much more severe deterioration to concrete than $\mathrm{NaCl}$ or $\mathrm{CaCl}_{2}$. This is due to the reaction between $\mathrm{Mg}^{2+}$ and the hydrated products in cement paste [2, 24-27]. As shown in Equation (1), $\mathrm{MgCl}_{2}$ can react with the cementitious calcium silicate hydrate $(\mathrm{C}-\mathrm{S}-\mathrm{H})$ present in the cement paste and produce non-cementitious magnesium silicate hydrate $(\mathrm{M}-\mathrm{S}-\mathrm{H})$ and calcium chloride $\left(\mathrm{CaCl}_{2}\right)$ :

$\mathrm{MgCl}_{2}+\mathrm{C}-\mathrm{S}-\mathrm{H} \rightarrow \mathrm{M}-\mathrm{S}-\mathrm{H}+\mathrm{CaCl}_{2}$

$\mathrm{MgCl}_{2}$ can also react with calcium hydroxide $\left(\mathrm{Ca}(\mathrm{OH})_{2}\right)$, another hydrated product present in the cement paste in addition to $\mathrm{C}-\mathrm{S}-\mathrm{H}$. As shown in Equation (2), this chemical reaction produces another non-cementitious material, magnesium hydroxide $\left(\mathrm{Mg}(\mathrm{OH})_{2}\right)$, commonly known as brucite.

$\mathrm{MgCl}_{2}+\mathrm{Ca}(\mathrm{OH})_{2} \rightarrow \mathrm{Mg}(\mathrm{OH})_{2}+\mathrm{CaCl}_{2}$

Since M-S-H and brucite are thermodynamically more stable than $\mathrm{C}-\mathrm{S}-\mathrm{H}$ and $\mathrm{Ca}(\mathrm{OH})_{2}$, the two reactions are highly likely to occur when $\mathrm{MgCl}_{2}$ is applied as a deicer onto con- crete. $\mathrm{M}-\mathrm{S}-\mathrm{H}$ and brucite have lower binding capacity than C-S-H and $\mathrm{Ca}(\mathrm{OH})_{2}$, and their formation in concrete thus significantly degrades concrete strength while increasing porosity.

In addition, great expansive forces usually accompany the formation of brucite, which further accelerates the concrete deterioration process. As a result, concrete degradation due to the reaction of $\mathrm{Mg}^{2+}$ with cement paste has been recognized as one of the major mechanisms through which $\mathrm{MgCl}_{2}$ deicer affects the durability of concrete structures [24, $25,27,28]$.

The aforementioned $\mathrm{MgCl}_{2}$ impacts on concrete are substantiated further by research based on field data [25]. In Iowa, core samples taken from existing concrete structures aged from eight to forty years all contained dolomitic limestone aggregates. The study revealed that $\mathrm{MgCl}_{2}$ deteriorated concrete by promoting expansion of the concrete through the formation of brucite and growth of other detrimental minerals. It was also reported that $\mathrm{NaCl}$ showed less detrimental effect than $\mathrm{MgCl}_{2}[25,29,30]$.

Detailed information regarding the mechanism of $\mathrm{MgCl}_{2}$ deteriorating concrete material can be found in many research studies. The consensus is that $\mathrm{Mg}(\mathrm{OH})_{2}$ and $\mathrm{M}-\mathrm{S}-\mathrm{H}$ are the most predominant reaction products, formation of which eventually leads to the degradation of concrete when $\mathrm{MgCl}_{2}$ is applied as a deicer [31-34], although different mechanisms were proposed for the formation and behavior of $\mathrm{Mg}(\mathrm{OH})_{2}$.

A recent laboratory study reported the formation of another potentially detrimental phase, calcium oxychloride $\left(3 \mathrm{CaO} \cdot \mathrm{CaCl}_{2} \cdot 15 \mathrm{H}_{2} \mathrm{O}\right)$, formed in cement mortars exposed to $15 \% \mathrm{MgCl}_{2}$ solutions for 84 days, as confirmed by optical microscopy, scanning electron microscopy (SEM), and microanalysis [35]. The proposed mechanism was based on Equations (2) and (3):

$3 \mathrm{Ca}(\mathrm{OH})_{2}+\mathrm{CaCl}_{2}+12 \mathrm{H}_{2} \mathrm{O} \rightarrow 3 \mathrm{CaO} \cdot \mathrm{CaCl}_{2} \bullet 15 \mathrm{H}_{2} \mathrm{O}$

The petrographic evidence indicated that platey calcium oxychloride crystals and their carbonate-substituted phase precipitated in air voids and cracks by consuming portlandite $\left(\mathrm{Ca}(\mathrm{OH})_{2}\right)$. In addition, Friedel's salt was detected in the specimens analyzed [35]. In another laboratory study by the same group, the structures of brucite were also observed in the outer layers of the PCC specimens exposed to concentrated $\mathrm{MgCl}_{2}$ [2].

The difficulty of constructing durable concrete dams in salt mines led to research efforts in Poland investigating the long-term behavior of cement pastes exposed to a strong chloride solution, predominantly composed of $\mathrm{NaCl}, \mathrm{MgCl}_{2}$, and $\mathrm{KCl}$ [36]. Kurdowski found two cements: high-alumina cement and alkali activated slag, performed particularly well for over seven years because a stable skin-like layer of low permeability formed and protected the concrete core. Even after fifteen years the high-alumina cement had high strength and showed no deterioration. Portland and slag cements, however, were found to be particularly vulnerable to deterioration or unstable layers of chemical products. The difference is attributed to the higher porosity of Portland and slag cements [36]. 


\section{Calcium Chloride $\left(\mathrm{CaCl}_{2}\right)$}

$\mathrm{CaCl}_{2}$ has been found to have a detrimental effect falling between that caused by $\mathrm{NaCl}$ and $\mathrm{MgCl}_{2}$. It has also been found that concrete specimens exposed to $\mathrm{CaCl}_{2}$ deteriorated in a similar pattern to those exposed to $\mathrm{MgCl}_{2}$, although at a slower pace and to a less severe degree. As shown in Equation (3), $\mathrm{CaCl}_{2}$ can also react with $\mathrm{Ca}(\mathrm{OH})_{2}$ and form a hydrated calcium oxychloride [2,37].

At temperatures ranging from 4.4 to $10^{\circ} \mathrm{C}$, hydrated calcium oxychloride can be generated in a relatively short period of time once $\mathrm{CaCl}_{2}$ is available. This reaction adds additional stress to the concrete matrix. A recent study [38] provided further evidence for this mechanism of $\mathrm{CaCl}_{2}$ attack in concrete.

The damaging impact of $\mathrm{CaCl}_{2}$ on concrete was examined in a comprehensive study [16] conducted at Iowa State University. The study included five deicing chemicals $\mathrm{NaCl}, \mathrm{CaCl}_{2}$ with and without a corrosion inhibitor, $\mathrm{KAc}$, and an agricultural product as well as freezing/thawing and wetting/drying exposure conditions. Comprehensive damaging criteria were set up and examined for the paste and concrete subjected to these deicing chemicals, including mass loss, scaling, compressive strength, chemical penetration, and microstructure of the paste and concrete. The deicing chemicals tested were found to penetrate into a given paste and concrete at different rates, leading to different degrees of damage. The two $\mathrm{CaCl}_{2}$ solutions caused the most severe damage compared to the others. The addition of the corrosion inhibitor in the $\mathrm{CaCl}_{2}$ solutions delayed the onset of damage, but failed to reduce the ultimate damage. Leaching of calcium hydroxide accompanied by some chemical alterations in concrete was also observed for specimens exposed to chlorides.

\subsection{Deicer Aggravating Aggregate-Cement Reactions}

\section{Chloride-Based Deicers Affecting ASR-An Anion-Oriented Chemical Process}

Alkali silica reaction (ASR) is a deleterious process caused by the chemical reaction between available alkalis from the cement paste and reactive silica in the aggregate of PCC. In ASR, the chemical reaction between hydroxyl $\left(\mathrm{OH}^{-}\right)$ associated with sodium $\left(\mathrm{Na}^{+}\right)$and potassium $\left(\mathrm{K}^{+}\right)$and reactive forms of silica produces a gel that expands when sufficient moisture is available. The expansion of the gel can produce internal stress great enough to cause cracks in both cement paste and aggregates. Typical ASR distress is manifested by cracking, popouts and expansion.

ASR was first discovered as a stress to concrete structures in the United States by Stanton in 1940 [39]. Failure of concrete structures later ascribed to ASR can be dated back to the late 1920s. Reactive aggregates, available alkalis and sufficient water are three prerequisites for ASR to occur. ASR has been conventionally controlled by limiting alkali content in cement and selecting aggregates of good quality.

Extensive research suggests that $\mathrm{NaCl}$ can initiate and/or accelerate ASR by supplying additional alkalis to concrete [40-46]. An increase in $\mathrm{pH}$ of the concrete pore solution has been frequently observed and commonly proposed as the principal cause for the exacerbation of ASR in PCC exposed to $\mathrm{NaCl}[42,44,47]$. Nevertheless, this process was found to be quite slow and might be masked by other short-term effects. Equation (4) presents the mechanism of the $\mathrm{pH}$ increase in concrete pore solution resulting from the dissolution of $\mathrm{Ca}(\mathrm{OH})_{2}$ in the presence of sodium chloride.

$2 \mathrm{NaCl}+\mathrm{Ca}(\mathrm{OH})_{2} \leftrightarrow \mathrm{CaCl}_{2}+2 \mathrm{NaOH}$

The $\mathrm{Cl}^{-}$ions from $\mathrm{NaCl}$ might also accelerate ASR when the $\mathrm{OH}^{-}$concentration remains above a certain limit $[45,48]$. It was reported that high-alkali concrete exposed to $\mathrm{NaCl}$ solution expanded even more than high-alkali concrete exposed to $\mathrm{NaOH}$. This was attributed to the combined effects of ASR and the formation of expansive chloroaluminates [49]. In contrast, low-alkali concrete was sufficiently protected against ASR when exposed to $\mathrm{NaCl}$ [49].

For high-alkali concrete that is already affected by ASR, map cracking can occur at the surface due to a decrease in $\mathrm{pH}$ in the near-surface layer of concrete. This has been observed in field specimens indicating that chloride ions traveled less than $100 \mathrm{~mm}$ inside the ASR-affected concrete. Measurements of core samples from concrete structures exposed to $\mathrm{NaCl}$ deicer indicated that most chlorides existed in the water-soluble form. SEM observations and microprobe analyses on mortar bars immersed in $\mathrm{NaCl}$ solution also suggested that binding of $\mathrm{Cl}^{-}$ions in chloroaluminates or cement hydrates was a long-term process, which could be promoted at higher initial alkali concentrations [50]. A SEM/ Energydispersive X-ray (EDX) investigation of cracking deterioration observed in a 3-year-old pavement in central Iowa revealed that ettringite-filled air voids were centers of pressure causing the cracks, instead of ASR that might have been incorrectly identified [51].

It should be noted that the accelerating effect of $\mathrm{NaCl}$ on ASR is a slow process, and stress to the concrete surface may be more likely caused by physical mechanisms such as salt scaling rather than chemical mechanisms [25]. Such a conclusion was made based on a laboratory observation where the $0.75 \mathrm{M} \mathrm{NaCl}$ solution caused more extensive deterioration to the concrete surface than the 3.0M one [25].

As reported in literature, $\mathrm{CaCl}_{2}$ and $\mathrm{MgCl}_{2}$ do not have as obvious an effect on ASR as $\mathrm{NaCl}$. A possible reason is that both $\mathrm{Ca}^{2+}$ and $\mathrm{Mg}^{2+}$ cations can react with the free hydroxyl ions $\left(\mathrm{OH}^{-}\right)$in the concrete pore solution and form products that are less soluble in water than $\mathrm{NaOH}$ or $\mathrm{KOH}$. Therefore, exposure of concrete to $\mathrm{CaCl}_{2}$ or $\mathrm{MgCl}_{2}$ tends to decrease the $\mathrm{pH}$ value in the pore solution. As a consequence, the accelerating effect of $\mathrm{Cl}^{-}$on ASR, if any, might be masked by the more dominant effect of the reaction between $\mathrm{Ca}^{2+}$ and $\mathrm{Mg}^{2+}$ cations with $\mathrm{OH}^{-}$in the cement paste.

Prezzi et al. [52] stress the need for laboratory tests that simulate actual field conditions to truly determine how $\mathrm{CaCl}_{2}$ and $\mathrm{MgCl}_{2}$ deicers affect ASR. In their study, $\mathrm{CaCl}_{2}$ and $\mathrm{MgCl}_{2}$ seemed to actually help reduce ASR-related expansions when added to concrete during mixing operations. When $\mathrm{NaOH}, \mathrm{KOH}, \mathrm{LiOH}, \mathrm{NaCl}, \mathrm{KCl}, \mathrm{CaCl} 2, \mathrm{MgCl}_{2}$, and $\mathrm{AlCl}_{3}$ were introduced to new concrete samples as admixtures and then tested according to ASTM C 1260, it was found that samples corresponding to chlorides with monovalent cations had greater ASR expansion than reference concrete specimens, while the divalant and trivalent cations generally had reduced expansions [52]. While this is in contrast 
to findings from a previous study [48] in which $\mathrm{CaCl}_{2}$ accelerated ASR, the test temperature and salt concentrations were different in these two studies and thus making it difficult to directly compare the research findings. Yet another study [53] tested ASR gel soaked in a solution consisting of $0.7 \mathrm{M} \mathrm{NaOH}$ and $0.1 \mathrm{M} \mathrm{CaCl}_{2}$, where a non-expansive reaction product formed and the ASR gel did not repolymerize.

\section{$\mathrm{CaCl}_{2}$ and $\mathrm{MgCl}_{2}$ Affecting ACR-A Cation-Oriented Chemical Process}

Another deleterious process is commonly observed in concretes with a short service life. The principal reaction has the nature of an alkali-dolomite reaction between coarse aggregates containing reactive dolomite (calcium magnesium carbonate-i.e., $\left.\mathrm{CaMg}\left(\mathrm{CO}_{3}\right)_{2}\right)$ and cement paste, recognized as Alkali-Carbonate Reaction (ACR).

In ACR, dolomite from the aggregate reacts with $\mathrm{OH}^{-}$in the cement paste to free magnesium cations $\left(\mathrm{Mg}^{2+}\right)$ and carbonate anions $\left(\mathrm{CO}_{3}{ }^{2-}\right) . \mathrm{Mg}^{2+}$ then precipitates as brucite, while $\mathrm{CO}_{3}{ }^{2-}$ reacts with portlandite from the cement to form calcite $\left(\mathrm{CaCO}_{3}\right)$ and $\mathrm{OH}^{-}$. The formation of brucite and calcite leads to crystal growth and thus increased pressure in concrete. This, together with the hydration state changes due to magnesium chloride hydrates, eventually leads to expansion and rapid deterioration of the concrete.

Both $\mathrm{MgCl}_{2}$ and $\mathrm{CaCl}_{2}$ deicers are known to deteriorate concretes containing reactive dolomite aggregates by accelerating ACR. $\mathrm{MgCl}_{2}$ contributes $\mathrm{Mg}^{2+}$ cations that can directly participate in the formation of brucite, whereas $\mathrm{CaCl}_{2}$ was found to accelerate ACR by enhancing the dedolomitisation reactions, releasing magnesium to form brucite and M-S-H $[26,27]$. No literature was found to report potential effects of $\mathrm{NaCl}$ on ACR.

\section{Acetate/Formate-Based Deicers Affecting ASR-An Anion- Oriented Chemical Process}

The last decade has seen an increase in the premature deterioration of PCC pavements, which coincided with the introduction of alternative deicers (KAc, NaAc, and $\mathrm{NaFm}$ ) for winter maintenance. Such deicers have been used more extensively and for more years in European countries for winter maintenance than in the United States [54]. The degree of distress in the PCC of European facilities ranges from mild to severe, in terms of surface cracking and repair and rehabilitation efforts.

Recent research conducted at Clemson University found that the acetate/formate-based deicers could induce increased levels of expansion in concrete with aggregates susceptible to ASR, and could trigger ASR in concrete that previously did not show susceptibility to ASR [55-57]. The laboratory results from a modified ASTM C 1260 mortar bar test and a modified ASTM C 1293 concrete prism test indicated that both KAc- and NaAc-based deicer solutions showed significant potential to promote ASR in specimens containing reactive aggregates. Such solutions were also found to cause more rapid and higher levels of expansion within 14 days of testing and to lead to lower dynamic moduli of elasticity, compared with $1 \mathrm{~N} \mathrm{NaOH}$ solution [56]. Increasing temperature or deicer concentration was found to accelerate the deleterious effects of deicers on the ASR in concrete.
Limited existing laboratory studies indicated that acetatebased deicers could cause or accelerate ASR distress in the surface of PCC pavement by increasing the $\mathrm{pH}$ of concrete pore solution. PCC pavements that were otherwise resistant to ASR might show rapid deterioration when exposed to these high-alkali solutions. The nature of the reactions associated with increased expansions in mortar bar tests remains unclear to date due to limited research conducted on this topic. It was proposed that such deicers react with one of the major hydrated products-portlandite-resulting in higher $\mathrm{pH}$ of the concrete pore solution. The high $\mathrm{pH}$ resulting from these interactions is likely to have an accelerating effect on the expansions due to ASR. This mechanism was substantiated by SEM/EDX investigation of mortar bars after deicer immersion, which was unable to detect portlandite in the cement paste [58]. Furthermore, the concrete specimens exposed to KAc deicer showed presence of certain secondary reaction products, the effect of which on the PCC durability merits further investigation [59].

Efforts have been made to mitigate ASR by adding various admixture materials. Research sponsored by the Federal Highway Administration (FHWA) used lithium compounds to successfully reduce ASR induced by the deicers [60]. The effectiveness of other supplementary cementing materials (e.g., selected fly ash and slag) was also evaluated in reducing the ASR potential in the presence of KAc deicer. The effectiveness of fly ash in mitigating ASR in the presence of KAc was found dependent on the lime content, as well as the dosage level of the fly ash and the aggregate reactivity. Fly ash with lower lime content was generally more effective in reducing the expansions [61], whereas high-lime fly ash was found ineffective due to its possible negative interactions with the deicer [62]. At the 50\% cement replacement level, slag appeared to be effective in mitigating expansions in both KAc deicer solution and $1 \mathrm{~N} \mathrm{NaOH}$ solution [62]. The addition of lithium nitrate to either KAc deicer solution or mortars alone was found to effectively reduce the mortar expansions [62].

\section{DEICER EFFECTS ON ASPHALT CONCRETE}

Of the two major types of pavements-PCC pavement and asphalt pavement-the latter is generally believed to be less effected by deicers. This is attributable to the relatively high chemical resistance that asphalt binder demonstrates in the presence of chloride-based deicers. Thus far, there are no specific guidelines established in the United States for application of deicers on asphalt pavements and little fundamental research carried out in investigating the asphalt/bitumendeicer reaction, although more severe loss of skid resistance on asphalt surface has been observed by state and federal highway agencies with the application of various road salts [63]. Current research studying deicers effects on asphalt pavement is focused on improving surface skid resistance of the pavements of different mix types.

\subsection{Deicer Impacts on Skid Resistance}

During the 1976-1977 winter season, FHWA sponsored studies in the states of Maine, Michigan, Utah, and Vermont to determine if more sodium chloride was needed to clear open-graded asphalt friction courses during winter storms than was needed to clear conventional asphalt pavements [64]. It was found that the clearing rates and appearance of 
open-graded and dense-graded pavements were different. Dense-graded pavement showed occasional faster clearing than open-graded pavements. The open-graded pavement, however, seemed to provide a superior skid-resistant surface during most storms without more salt used to maintain the surface [64].

Open-graded asphalt mixes commonly used in asphalt pavements fall into three categories: open-graded friction course (OGFC), stone matrix asphalt (SMA), and opengraded base material (OGBM), of which only OGFC and SMA are used as surface course. Accordingly, previous research related to deicer effects on the skid resistance of pavement surfaces focused mainly on these two types of mixes. OGFC and SMA are generically referred to as opengraded mixes (OGMs) or open-graded pavements (OGPs) in deicer studies. OGMs, especially the OGFC, are known to offer lower noise and higher friction between tires and road surface. However, in terms of the skid resistance when deicers are applied, the limited research efforts thus far have yielded quite contradictory conclusions regarding their performance under winter conditions. While some reports indicated that these mixes were problematic when subjected to wet-freeze conditions [65, 66], others reported enhanced performance [67]. Such risks, if proven to be true, need to be addressed, considering the increased wet-freeze frequencies on pavement surfaces when deicers are applied.

The Virginia Department of Transportation sponsored a study [68] to examine its winter maintenance techniques of applying sodium chloride in granular, pre-wetted, and liquid forms. The snow removal and ice control operations followed the recommendation by the FHWA Project TE-28. There were no significant differences in the performance of the different surface mixes, including OGFC and densegraded mixes. A more recent study [69] by the Oregon Department of Transportation was conducted on the effects of liquid magnesium chloride on OGP. Skid tests were performed on four sections of two different highways in Oregon under three conditions: 1) no deicer application; 2) after a deicer application rate of 15 gallons/lane mile; and 3) after a deicer application rate of 30 gallons/lane mile. The results of the skid tests showed that the application of deicer appeared to have little if any effect on the Friction Number (FN), which were all well above the FHWA-recommended minimum FN values.

Due to harsher winter weather that produces more snow and ice, Nordic countries and Canada use more deicers on highways and airport runways than the United States, leading to more extensive research conducted in these areas. Fundamental research has been conducted in these countries to investigate the potential reactions between asphalt materials and various deicers.

\subsection{Deicers Affecting Pavement Structure}

Thermal cracking, differential heaving, and loss of bearing capacity during spring thaw are often identified as the main mechanisms of pavement deterioration in cold climates. Frost action within the pavement granular layers can be aggravated by an ice enrichment process and differential freezing conditions associated with the contamination of the base material by deicing salt [70].
A comprehensive laboratory study evaluated the relative destructive effects of various deicers on asphalt pavement, considering the effect of freeze/thaw cycles [71, 72]. This study involved actual aggregates and asphalt specimens cored from the field, as well as four types of deicers used on both highway and airport pavements, namely, urea, $\mathrm{NaCl}$, $\mathrm{NaFm}$, and KAc. Various degrees of material disintegration as a combined result of frost action and deicers were observed, revealing that the effect from freeze/thaw cycling was significant whereas the effects of different deicers on both the aggregates and the asphalt concrete mixes varied. The extent of damage due to freeze/thaw cycling in distilled water was less than that caused by any deicer used. A critical range of deicer concentration was found to exist between $1 \%$ and $2 \%$ by weight of solid deicer to deicer solution, in which the maximum damaging effect of deicers to the aggregate was observed. The limestone aggregates showed a higher resistance to disintegration than the quartzite aggregates when subjected to freeze/thaw cycles in the presence of the deicers. The urea was found to have the highest damaging effect among all the deicers on both the aggregates and asphalt concrete samples, while the least damaging deicer for limestone was $\mathrm{NaCl}$ and for quartzite was KAc.

The indirect tensile strengths (ITS) of the samples exposed to deicers were mostly higher than those exposed to distilled water, while all of them were found to be significantly lower than those of the intact samples. However, there was no significant deterioration identified for the mechanical properties of the samples exposed to $\mathrm{KAc}, \mathrm{NaFm}$, or $\mathrm{NaCl}$, relative to distilled water. Conditioning asphalt samples using freeze-thaw cycles in the presence of a deicer solution also caused a decrease in the modulus of elasticity. The lowest average elastic modulus was associated with the samples in urea, and visual inspection indicated significant damage by urea [72]. Based on weight measurements and density calculations, asphalt mix sample immersed in NaFm experienced the most disintegration after 25 cycles, whereas urea (followed by KAc) was the most detrimental deicer after 50 cycles [73]. Exposure to freeze/thaw cycles and deicers was found to affect the viscosity of the recovered asphalt binder and the gradation of recovered aggregates. The freeze/thaw cycles seemed to result in soft asphalt binder, while the deicers caused asphalt hardening. However, the authors noted that these findings were inconclusive due to the difficulties involved in testing and the inaccuracies in measuring viscosity of the recovered asphalt. Overall, this laboratory investigation found urea to be the most detrimental deicer, while the other deicers "induced relatively small damage, comparable to that caused by distilled water" [71]. It should be noted that chemical reactions might have been slowed by the low temperatures involved in this study and that damage in the field could occur as a result of reactions between deicer residues and asphalt during hot summer temperatures [71].

A follow-up study was conducted at higher temperatures on asphalt pavement samples taken from the Dorval International Airport (Montreal, Canada) to clarify the role played by the deicers in asphalt deterioration, and to determine whether the damage was attributable to the physical freeze/thaw action. Only 15 freeze/thaw cycles were performed before subjecting some samples to $40 \mathrm{wet} / \mathrm{dry}$ cycles at $40^{\circ} \mathrm{C}$. This research confirmed the previous finding that softening occurs during freeze/thaw and exposure to deicers 
causes hardening. After the freeze/thaw and wet/dry cycles, the asphalt samples in NaAc showed the greatest loss of strength and elasticity, followed by those in NaFm. Interestingly, all samples showed increased strength after the warm wet/dry cycles and all except $\mathrm{NaFm}$ and $\mathrm{NaAc}$ showed increased elasticity after the warm wet/dry cycles. However, the dry samples not exposed to freeze/thaw or wet/dry cycles had the greatest elasticity and nearly the highest strength. Overall, the Canadian studies did not indicate significant damaging effects of $\mathrm{KAc}$ and $\mathrm{NaFm}$ on asphalt pavement $[72,74]$. It should be cautioned, however, that these results were based on laboratory experiments with only two samples of asphalt pavement and the mix design for each pavement was undeterminable from the reports.

\subsection{Acetate/Formate-Based Deicer Affecting Airfield Asphalt Pavements}

Concurrent to the use of acetate/formate-based deicers in the 1990s, asphalt pavement in Europe saw an increase in pavement durability problems. At some Nordic airports, these problems emerged as degradation and disintegration of asphalt pavement, softening of asphalt binders, and stripping of asphalt mixes occurring together with loose aggregates on the runways [75, 76]. Such problems were not identified prior to the airports changing from urea to KAc- and KFmbased deicers.

In 2001, serious asphalt durability problems were identified at airports in Nordic countries that used acetate/formatebased deicers [75]. Heavy binder bleeding and serious stripping problems were observed occurring together with loss of asphalt stability. Soft, sticky, and staining binder came to the surface, often leaving strong stains on electrical devices and on the airplanes. The binder of the asphalt base layer was "washed off", and the aggregates experienced a severe loss of strength. In the laboratory, tests indicated chemical changes in the binder after exposure to the deicer in the form of emulsification, distillation, and an increased amount of polycyclic aromatic hydrocarbons (PAHs). A field investigation was conducted subsequently that confirmed the deleterious effects of acetate-based deicer on the asphalt pavement. The bitumen and the mastic squeezed to the surface of the core, and the concentration of the deicer had a clear influence on its solubility. Some bitumen was dissolved into the pore liquid, and pure stone particles were found inside the core. The limestone filler was found fully dissolved by the deicer liquid and the rest of the mastic became brittle and grey-colored. A large increase in the porosity of asphalt was also noticed $[75,76]$.

To address the observed problems, a joint research program-the JÄPÄ Finnish De-icing Project-was established to conduct extensive laboratory and field investigations on this subject. The goal of J $\ddot{A P A ̈}$ was to provide answers to three fundamental concerns-i.e., how the damage is generated, how to determine the compatibility between asphalt and deicing materials, and whether it is possible to prevent damage by mix design. The research showed that formate/acetatebased deicers significantly damaged asphalt pavements. The damaging mechanism seemed to be a combination of chemical reactions, emulsification and distillation, as well as generation of additional stress inside the asphalt mix. Asphalt binders soaked in the deicer solution were found to have lower softening points and tended to dissolve at temperatures as low as $20^{\circ} \mathrm{C}$. Asphalt mixes soaked in the deicer solution were found to have lower surface tensile strength and lower adhesion [75, 76]. It seemed clear that deicer (formate or acetate), water or moisture, and heat were necessary for the damage to occur. In the field, such damage mainly occurred during the repaving process or on hot summer days with residual deicers from the winter season, as dynamic loading and unloading reduced the time it took for damage to occur.

A recent study [77] at the Western Transportation Institute's Corrosion and Sustainable Infrastructure Laboratory was able to reproduce acetate-induced emulsification of asphalt similar to the field observations at Nordic airports. Aqueous solution tests of asphalt binder in water and four NaAc solutions of different concentrations (5\% to $40 \%$ ) showed a bilinear trend of weight loss increasing with the $\mathrm{NaAc}$ concentration. Both visual inspection and optical microscopy indicated that a significant amount of asphalt emulsification occurred in $\mathrm{NaAc}$, but not in water or aqueous solutions of $\mathrm{NaCl}$ or $\mathrm{NaOH}$ with a $\mathrm{pH}$ of 9 (equivalent to the measured $\mathrm{pH}$ of $40 \% \mathrm{NaAc}$ solution). For the two tested asphalt binders, PG 58-22 exhibited slightly higher emulsification than PG 67-22. In the CMA aqueous solution, asphalt emulsification occurred similarly to that in NaAc. These results confirmed that asphalt emulsification should be attributed to the acetate anion, $\mathrm{CH}_{3} \mathrm{COOH}^{-}$, and excluded the possibility that high alkalinity was responsible for the asphalt emulsification in NaAc. Asphalt emulsification also occurred in a $\mathrm{NaFm}$ aqueous solution.

The effects of NaAc on asphalt mixes were examined by conducting a modified ASTM D 3625-96 Boiling Water Test, which was originally designed to test the susceptibility of asphalt mixes to moisture damage by accelerating the effect of water on bituminous-coated aggregate with boiling water. Stripping occurred for both crushed gravel and limestone aggregate particles included in the asphalt mix exposed to NaAc, suggesting that aggregate properties play at most a secondary role in asphalt emulsification [77]. A significant amount of aggregate was stripped after exposure to the $\mathrm{NaAc}$ solutions and the aggregate stripping followed a bilinear tread with weight loss increasing with the NaAc concentration.

Phase I of the Airfield Asphalt Pavement Technology Program Project 05-03: Effect of Deicing Chemicals on HMA Airfield Pavements includes a literature review, interviews with managers at 36 airports that use deicers and have asphalt pavement, as well as laboratory testing. Seven airports indicated that pavement deterioration had occurred, but the cause was unknown except in one case most likely attributable to the type and source of asphalt binder and aggregate. Preliminary laboratory testing of asphalt pavement samples composed of either a chert gravel or diabase with two binders (PG 64-22 and PG 58-28) exposed to KAc and $\mathrm{NaFm}$ was conducted. The presence of PAHs was inconclusive after vacuum-induced saturated samples were stored for four days at $60^{\circ} \mathrm{C}$. However, significant generation of carboxylate salts had developed after the asphalt mixes were exposed to the deicers, although this may not be related directly to deicer-induced damage. ITS tests showed PG 64-22 to be "somewhat more resistant" [78], and that chert gravel had significantly less strength when exposed to deicers com- 
pared to water. A long-term durability test developed by Advanced Asphalt Technologies also showed chert to be very susceptible to moisture damage, particularly when exposed to KAc or NaFm. Soundness tests of both types of aggregate in magnesium sulfate, $\mathrm{KAc}$, and $\mathrm{NaFm}$ were acceptable and also showed that direct attack on the aggregate by the deicers was not occurring [78].

The JÄPÄ-Finnish De-icing Project studied the ingredient materials in asphalt pavement individually and the roles they played in the damaging mechanism were ranked accordingly [79]. The key test results of each ingredient material are as follows.

\section{Effects of Formate/Acetate-Based Deicers on Aggregates}

The main reason for pavement damage was not due to poor quality of aggregates. Mineral aggregate might be a reason secondary to asphalt binders in pavement damage. The decomposition level of acidic aggregates was higher than for caustic aggregates, but was still acceptable. However attention should be paid to the weathering resistance of aggregates used in airfields to extend the lifespan of asphalt pavements.

\section{Physical Effects of Formate/Acetate-Based Deicers on Bi- tumen/Asphalt}

1) High density of deicer solution such as $1.34 \mathrm{~kg} / \mathrm{dm}^{3}$ for the $50 \%$ (by weight) solution enabled the deicer to penetrate into bitumen by gravity. 2) Very low surface tension between deicer chemicals and asphalt facilitated stripping and emulsification of asphalt mixes. 3) Formate/acetatebased deicers had $\mathrm{pH}$ values usually between 9 and 11, and the higher the $\mathrm{pH}$ the more aggressive the deicer would be. 4) Formate/acetate-based deicers were very hygroscopic, which kept the road surface constantly wet and retained water inside the asphalt to overfill the air voids.

\section{Chemical Effects of Formate/Acetate-Based Deicers on Bitumen/Asphalt}

When exposed to deicers, composition changes of bitumen/asphalt occurred in the hydrocarbon classification C10C40. When exposed to deicers, large organic molecules, such as the PAHs, grew in bitumen. Deicers in asphalt were found in both the liquid and gas phases. PAHs in the asphalt samples could migrate and become dissolved in the deicer.

\section{Failure Process of Asphalt Pavements}

Deicers migrate into the asphalt after application onto pavements and saturate asphalt mixes during the winter. The deicer solution intrudes into asphalt due to gravity and for other unknown reasons, especially when asphalt temperature rises significantly (a result of summer weather or laying hot asphalt). Due to the low surface tension between deicers and bitumen, the deicers are absorbed in the bitumen, which, in turn, starts to emulsify. It is possible that the chemical composition of the bitumen changes during emulsification. Due to emulsification the bitumen comes loose and the aggregate particles get cleaned, followed by bleeding and stripping.

The preliminary research by Advanced Asphalt Technologies suggested the damaging mechanism was mainly a disruption of the asphalt-aggregate bond due to ASR. Expansive pressures typical of ASR-damaged concrete were not perceived to be the problem, but rather the bond disruption and increased susceptibility to moisture damage. Advanced Asphalt Technologies is currently working on Phase II, which includes more significant laboratory testing and field investigations [78].

However, the research by Pan et al. at our research group [77] shows that: 1) asphalt emulsification occurrs in asphalt mixes with both reactive and non-reactive aggregates, and 2) asphalt emulsification does not occur in $\mathrm{NaOH}$ solutions of the same $\mathrm{pH}$ values as the $\mathrm{NaAc}$ solution, which indicates that asphalt emulsification may be a more critical mechanism of asphalt mix deterioration than ASR unless very reactive aggregates are used in the asphalt mix. We proposed a detailed and specific mechanism of acetate-induced asphalt emulsification based on contact between acetate anions $\left(\mathrm{CH}_{3} \mathrm{COOH}^{-}\right)$and asphalt, which can be greatly increased at high summer and/or re-paving temperatures due to the tendency of asphalt to swell. For $\mathrm{NaAc}$, aqueous solution tests of asphalt binder were performed at several concentrations and temperatures and the resulting suspended substance was examined using Fourier Transform Infrared Spectroscopy. No significant amounts of new chemicals were identified, and intermolecular binding between the acetate anion $\mathrm{CH}_{3} \mathrm{COOH}^{-}$and the alkane component of asphalt was inferred. Van der Waals forces anchor the lipophilic organic chain $\left(\mathrm{CH}_{3}^{-}\right)$of the acetate anion to the molecular chain of asphalt $\left(\mathrm{CH}_{3}-\mathrm{CH}_{2}-\right)$. At the same time, the hydrophilic polar end $\left(\mathrm{COO}^{-}\right)$of the acetate anion forms hydrogen bonds with water molecules and pulls on the asphalt, overcoming the intermolecular forces within the asphalt. Asphalt emulsion is maintained by Brownian motion and repulsive forces on the floccules. The emulsification of asphalt reduces the asphaltaggregate bond and can lead to adhesion failure in the pavement. There is also the potential that the aggregate preferentially bonds with the acetate anion, which has a higher polarity than the asphalt molecules [77].

To prevent or mitigate the effects of deicers on asphalt pavement, the first and most important countermeasure is to follow best possible practices in asphalt mix design and paving. Responses to an Airport Cooperature Research Program survey point towards adoption of some of these preventive measures: one European airport reduced asphalt pavement air void to $3.0 \%$; another European airport indicated polymer-modified binder is used; and one U.S. airport changed the asphalt binder to PG 76-32 citing current Federal Aviation Administration specifications [54]. Nonetheless, the JÄPÄ Project research showed that the resistance of asphalt pavement to deicers can be improved only partially by mix design. According to the laboratory results, binders with high viscosity or polymer-modified binders were recommended when formate/acetate-based deicers were to be used. Highquality (sound) aggregates could also improve the durability of asphalt pavements in presence of such deicers, and so could aggregates with a higher $\mathrm{pH}$. The void contents of the asphalt mixes were recommended to be kept low enough to limit deicer solution in pores. Other suggestions to prevent asphalt damage are summarized below [80]:

1. Prefer harder bitumen (penetration max 70/100) or modified bitumen.

2. Use alkaline aggregates and avoid limestone filler.

3. Test the compatibility of the materials in advance. 
4. The most secure way is not to use acetates and formates on asphalt structures.

5. When repaving, the wearing course containing residual deicers must be milled away, and recycled asphalt pavement should not be used if it is heavily contaminated [81].

\section{CONCLUSIONS}

Deicers may pose detrimental effects on concrete infrastructure and thus reduce concrete integrity (as indicated by expansion, mass change and loss in the dynamic modulus of elasticity) and strength. Such risks of deicers on the durability of PCC structures and pavements exist through three main pathways: 1) physical deterioration of the concrete through such effects as salt scaling; 2) chemical reactions between deicers and cement paste (a cation-oriented process, especially in the presence of $\mathrm{Mg}^{2+}$ and $\left.\mathrm{Ca}^{2+}\right)$; and 3) deicers aggravating aggregate-cement reactions (including an anionoriented process in the case of chlorides, acetates, and formates affecting ASR; and a cation-oriented process in the case of $\mathrm{CaCl}_{2}$ and $\mathrm{MgCl}_{2}$ affecting ACR). The use of proper air entrainment, high-quality cementitious materials and aggregates, and mineral admixtures is promising in mitigating the deicer impact on PCC.

The PCC pavement exposed to $\mathrm{MgCl}_{2}$ and $\mathrm{CaCl}_{2}$ deicers may deteriorate due to the chemical reactions between deicers and cement paste. In the case of $\mathrm{MgCl}_{2}$ deicers, $\mathrm{Mg}(\mathrm{OH})_{2}$ and $\mathrm{M}-\mathrm{S}-\mathrm{H}$ are the most predominant reaction products, formation of which eventually leads to the degradation of concrete. In the presence of $\mathrm{CaCl}_{2}$ deicers, PCC pavements deteriorate in a similar pattern to those exposed to $\mathrm{MgCl}_{2}$, although at a slower and less severe pace. $\mathrm{CaCl}_{2}$ can also react with $\mathrm{Ca}(\mathrm{OH})_{2}$ and form a hydrated calcium oxychloride and add additional stress to the concrete matrix.

Field applications of deicers onto PCC pavements and bridges have caused an increase in ASR occurrence. Extensive research suggests that $\mathrm{NaCl}$ can initiate and/or accelerate ASR by supplying additional alkalis to concrete. However, the deterioration of NaCl-based deicers on concrete structures by mechanism of ASR is heavily dependent on the thickness of concrete in PCC pavements and bridges. Formate/acetate-based deicers were also found to cause ASR distress in the surface of PCC pavement, by inducing high alkali solutions. $\mathrm{CaCl}_{2}$ and $\mathrm{MgCl}_{2}$ do not have as obvious an effect on ASR as $\mathrm{NaCl}$.

Both $\mathrm{MgCl}_{2}$ and $\mathrm{CaCl}_{2}$ deicers are known to deteriorate concretes containing reactive dolomite aggregates by accelerating ACR, where brucite and portlandite crystals are precipitated and exert additional pressure in the concrete. $\mathrm{MgCl}_{2}$ contributes $\mathrm{Mg}^{2+}$ cations that can directly participate in the formation of brucite, whereas $\mathrm{CaCl}_{2}$ was found to accelerate ACR by enhancing the de-dolomitisation reactions, releasing magnesium to form brucite and $\mathrm{M}-\mathrm{S}-\mathrm{H}$. No literature was found to report potential effects of $\mathrm{NaCl}$ on ACR.

Asphalt pavement is generally believed to be less affected by deicers, although a more severe loss of skid resistance on asphalt surfaces has been observed by state and federal highway agencies with the application of various road salts. Dense-graded pavement showed occasional faster clearing than open-graded pavements. The open-graded pavement, however, seemed to provide a superior skid-resistant surface during most storms without more salt applied to maintain the surface. Thus, while their impact on skid resistance is still inconclusive, deicers are known to affect pavement structure and cause loss of strength and elasticity. Exposure to freeze/thaw cycles and deicers was found to affect the viscosity of the recovered asphalt binder and the gradation of recovered aggregates.

The extent of asphalt pavement damage due to freeze/thaw cycling in distilled water was less than that caused by any deicer used (urea, $\mathrm{NaCl}, \mathrm{NaFm}$, or KAc). A critical range of deicer concentration was found to exist between $1 \%$ and $2 \%$ by weight of solid deicer to deicer solution, in which the maximum damaging effect of deicers was observed for all types of deicer and aggregate. The limestone aggregates showed a higher resistance to disintegration than the quartzite aggregates when subjected to freeze/thaw cycles in presence of the deicers. The urea was found to have the highest damaging effect among all the deicers on both the aggregates and asphalt concrete samples.

Formate/acetate-based deicers were found to significantly damage asphalt pavements. The damaging mechanism seemed to be a combination of chemical reactions, emulsifications and distillations, as well as generation of additional stress inside the asphalt concrete. It seemed clear that deicers (formate or acetate), water or humidity, and heat were necessary for the damage to occur. Damage mainly occurred during the repaving process or in the long run in combination with hot summer days. Dynamic loading and unloading reduced the time it took for damage to occur.

\section{ACKNOWLEDGEMENTS}

The authors thank the Colorado Department of Transportation (CDOT) as well as the Research \& Innovative Technology Administration (RITA) at the U.S. Department of Transportation for providing financial support.

\section{ABBREVIATIONS}

$\begin{array}{lll}\mathrm{ACR} & = & \text { Alkali-carbonate reaction } \\ \mathrm{ASR} & = & \text { Alkali-silica reaction } \\ \mathrm{CaCl}_{2} & \text { Calcium chloride } \\ \mathrm{CMA} & = & \text { Calcium magnesium acetate } \\ \mathrm{C}-\mathrm{S}-\mathrm{H} & = & \text { Calcium silicate hydrate } \\ \mathrm{EDX} & = & \text { Energy-dispersive X-ray } \\ \mathrm{FHWA} & = & \text { Federal Highway Administration } \\ \mathrm{FN} & = & \text { Friction Number } \\ \mathrm{ITS} & = & \text { Indirect tensile strength } \\ \mathrm{KAc} & = & \text { Potassium acetate } \\ \mathrm{KFm} & = & \text { Potassium formate } \\ \mathrm{MgCl} & = & \text { Magnesium chloride } \\ \mathrm{M}-\mathrm{S}-\mathrm{H} & = & \text { Magnesium silicate hydrate } \\ \mathrm{NaAc} & = & \text { Sodium acetate } \\ \mathrm{NaCl} & = & \text { Sodium chloride } \\ \mathrm{NaFm} & = & \text { Sodium formate }\end{array}$




$\begin{array}{lll}\text { OGBM } & =\text { Open-graded base material } \\ \text { OGFC } & =\text { Open-graded friction course } \\ \text { OGM } & =\text { Open-graded mix } \\ \text { OGP } & =\text { Open-graded pavement } \\ \text { PAH } & =\text { Polycyclic aromatic hydrocaron } \\ \text { PCC } & =\text { Portland cement concrete } \\ \text { SEM } & =\quad \text { Scanning electron microscopy } \\ \text { SMA } & =\quad \text { Stone matrix asphalt } \\ \text { w/c } & =\text { Water to cement ratio }\end{array}$

\section{REFERENCES}

[1] X. Shi, L. Fay, Z. Yang, T. A. Nguyen, and Y. Liu, "Corrosion of deicers to metals in transportation infrastructure: introduction and recent developments $\%$ ", Corros. Reviews, in press, 2009.

[2] L. Sutter, K. Peterson, G. Julio-Betancourt, D. Hooton, T. Vam Dam, and K. Smith, "The deleterious chemical effects of concentrated deicing solutions on portland cement concrete", South Dakota Department of Transportation, Final Report SD2002-01-F, April 2008.

[3] X. Shi, L. Fay, M. M. Peterson, and Z. X. Yang, "A SEM/EDX study of the impact of diluted deicers on Portland cement concrete $\% 0 "$, Mater. Struct., under review, 2009.

[4] D. Darwin, J. Browning, L. Gong, and S. R. Hughes, "Effects of deicers on concrete deterioration", Structural Engineering and Materials Laboratory, SL Report 07-3, University of Kansas, Dec. 2007.

[5] M. C. Santagata and M. Collepardi, "The effect of CMA deicers on concrete properties", Cement Concr. Res., vol. 30, pp.1389-1394, Sept. 2000.

[6] M. C. Santagata and M. Collepardi, "Concrete deterioration caused by exposure to calcium-magnesium acetate aqueous solutions", in Proc. 2nd Int. Conf. On Concrete under Severe Conditions 2: Environment and Loading, N. Banthia, O. Gjorv, and K. Sakai, Eds. CONSEC'98, Troms, Norway, June 21-24, E\&FN Spon, London, UK, 1998, pp. 543-554.

[7] O. Peterson, "Chemical effects on cement mortar of calcium magnesium acetate as a deicing salt". Cement Concr. Res., vol. 25, no. 3, pp. 617-626, April 1995.

[8] ACI Committee 302, Guide for Concrete Floor and Slab Construction, ACI 302.1R-96, American Concrete Institute, Farmington Hills, Michigan, 1996.

[9] G. G. Litvan, "Phase transitions of adsorbates: VI, effect of deicing agents on the freezing of cement paste". J. Amer. Ceramic Soc., vol. 58, no. 1-2, pp. 26-30, Jan. 1975.

[10] C. Korhonen, Effect of high doses of chemical admixtures on the freeze-thaw durability of portland cement concrete. U.S. Army Corps of Engineers, Engineering Research and Development Center. ERDC/CRREL TR-02-5, Feb. 2002.

[11] J. Marchand, E. J. Sellevod, and M. Pigeon, "The deicer salt scaling deterioration of concrete-an overview", Presented at the Third CANMET/ACI International Conference on Durability of Concrete, Nice, France, 1994.

[12] M. Pigeon and R. Pleau, Durability of Concrete in Cold Climates. New York, NY: E and FN Spon, 1995.

[13] Transportation Association of Canada, "Syntheses of best practices - road salt management”, Sept. 2003. [Online]. Available: http://www.tac-atc.ca/english/informationservices/readingroom. cfm\#syntheses [Last Accessed November 17, 2008].

[14] B. T. Mussato, O. K. Gepraegs, and G. Farnden, "Relative effects of sodium chloride and magnesium chloride on reinforced concrete-the state of art", in Compendium of Papers CD for the Transportation Research Board 83rd Annual Meeting, Washington, D.C. Jan. 2004.

[15] D. B. McDonald and W. F. Perenchio, "Effects of salt type on concrete scaling", Concrete Intl., vol. 19, no. 7, pp. 23-26, July 1997.

[16] K. Wang, D. E. Nelsen, and W. A. Nixon. "Damaging effects of deicing chemicals on concrete materials", Cement Concr Comp., vol. 28, no. 2, pp.173-188, Feb. 2006.
[17] A. Al-Otoom, A. Al-Khlaifa, and A. Shawaqfeh, "Crystallization technology for reducing water permeability into concrete", Ind. Eng. Chem. Res., vol. 46, no. 16, pp. 5463-5467, Aug. 2007.

[18] D. Williams, Past and current practices of winter maintenance at the Montana Department of Transportation. White Paper, Dec. 2003. [Online]. Available http://www.mdt.mt.gov/publications/ docs/brochures/winter_maint/wintmaint_whitepaper.pdf [Last Accessed November 17, 2008].

[19] C. Öttl, "Frost/deicing salt resistance of concrete pavements with unsuitable air void characteristics", Otto Graf J., vol. 17, pp. 45-55, 2006. [Online]Available: http://www.mpa.uni-stuttgart.de/ publikationen/otto_graf_journal/ogj_2006/beitrag_oettl.pdf. [Last Accessed Nov. 17, 2008].

[20] J. Marchand, J. Maltais, Y. Marchabée, C. Tablot, and M. Pigeon, "Effects of fly ash on microstructure and deicer salt scaling of concrete", in Frost Resistance of Concrete: Proceedings of the International RILEM Workshop. M. J. Setzer and R. Auberg, Eds. E \& FN SPON. Essen, Germany, 1997.

[21] T. Naik, R. Kraus, B. Ramme, and Y. Chun, "Deicing salt-scaling resistance: laboratory and field evaluation of concrete containing up to 70\% Class C and Class F fly ash", J. ASTM Intl., vol. 2, no. 7, pp. 12, July/Aug, 2005.

[22] Q. Yang, S. Zhang, and X. Wu, "Deicer-scaling resistance of phosphate cement-based bind for rapid repair of concrete", Cement Concr. Res., vol. 32, no. 1, pp.165-168, Jan. 2002.

[23] J. M. Pitt, M. C. Schluter, D. Y. Lee, and W. Dubberke, "Effects of deicing salt trace compounds on deterioration of portland cement concrete", Final Report, Iowa Department of Transportation and Iowa Highway Research Board, Jan. 1987.

[24] R. D. Cody, P. G. Spry, A. M. Cody, and G.-L. Gan, "The role of magnesium in concrete deterioration", The Iowa Highway Research Board, Final Report-Iowa DOT HR-355, 1994.

[25] R. D. Cody, A. M. Cody, P. G. Spry, and G.-L. Gan, "Experimental deterioration of highway concrete by chloride deicing salts". Environ. Eng. Geosci., vol. 2, no. 4, pp. 575-588, Nov. 1996.

[26] J. Deja and G. Loj, "Effects of cations occurring in the chloride solutions on the corrosion resistance of slag cementitious materials", presented at Infrastructure Regeneration and Rehabilitation Improving the Quality of Life through Better Construction-A Vision for the Next Millennium, Sheffield, 1999.

[27] H. Lee, R. D. Cody, A. M. Cody, and P. G. Spry, "Effects of various deicing chemicals on pavement concrete deterioration", in Proceedings Mid-Continent Transportation Symposium, 2000.

[28] T. M. Balasubramanian, S. Srinivasan, K. Balakrishnan, and K. Saravanan, "Deterioration of concrete in industrial environments", Presented at 10th International Congress on Metallic Corrosion, Madras, India, 1987.

[29] A. M. Cody, R. D. Cody, H. Lee, and P. G. Spry, "Expansive mineral growth and concrete deterioration", Iowa State University, Ames, Final Report, Iowa DT HR-384, Sept. 1997.

[30] A. M. Cody, R. D. Cody, H. Lee, and P. G. Spry, "PCC pavement deterioration and expansive mineral growth", Presented at Crossroads 2000, Ames, Iowa, 1998.

[31] M. Moukwa, "Characteristics of the attack of cement paste by $\mathrm{MgSO}_{4}$ and $\mathrm{MgCl}_{2}$ from pore structure measurements", Cement Concr. Res., vol. 20, no. 1, pp.148-158, Jan. 1990.

[32] I. M. Helmy, A. A. Amer, and H. El-Didamony, "Chemical attack on hardened pastes of blended cements-Part 1: attack of chloride solutions", Zement-Kalk-Gips., vol. 44, no. 1, pp. 46-50, 1991.

[33] L. D. Wakeley, T. S. Poole, C. A. Weiss, and J. P. Burkes, "Geochemical stability of cement-based composites in magnesium brines", in Proceedings of the 14th International Conference on Cement Microscopy, Costa Mesa, CA, 1992.

[34] V. W. Rechenberg and H.-M. Sylla, "The effect of magnesium on concrete", ZKG Int., vol. 49, no. 1, pp. 44-56, 1996.

[35] L. Sutter, K. Peterson, S. Touton, T. Van Dam, and D. Johnston, "Petrographic evidence of calcium oxychloride formation in mortars exposed to magnesium chloride solution", Cement Concr. Res., vol. 36, no. 8, pp.1533-1541, Aug. 2006.

[36] W. Kurdowski, "The protective layer and decalcification of C-S-H in the mechanism of chloride corrosion of cement paste", Cement Concr. Res., vol. 34, no. 9, pp.1555-1559, Sept. 2004

[37] S. Monosi and M. Collepardi, "Research on $3 \mathrm{CaO} \cdot \mathrm{CaCl} 2 \cdot 15 \mathrm{H} 2 \mathrm{O}$ identified in concretes damaged by $\mathrm{CaCl} 2$ attack", Il Cemento, vol. 87, pp. 3-8, Jan/March 1990. 
[38] L. Sutter, T. Van Dam and K. R. Peterson, " Long term effects of magnesium chloride and other concentrated salt solutions on pavement and structural Portland cement concrete-phase I results", in Compendium of Papers CD for the Transportation Research Board 85th Annual Meeting, Washington, D.C, Jan. 2006.

[39] T. E. Stanton, "Expansion of concrete through reactions between cement and aggregate", in Proceedings of American Society of Civil Engineers, vol. 66, 1940, pp.1781-1811.

[40] S. Chatterji, N. Thaulow, A. D. Jensen, "Studies of ASR: Part IV: effect of different alkali salt solutions on expansion", Cement Concr. Res., vol. 17, no. 5, pp. 777-783, Sept. 1987.

[41] M. Kawamura, K. Takemoto, and M. Ichise, "Influences of the alkali-silica reaction on the corrosion of steel reinforcement in concrete", in Proceedings of the 8th International Conference on AAR, Society of Materials Sciences, Kyoto, Japan, 1989, pp.115-120.

[42] P. J. Nixon, C. L. Page, I. Canham, and R. Bollinghaus, "Influence of sodium chloride on the ASR", Adv. Cement Res., vol. 1, pp. 99$105,1988$.

[43] R. G. Sibbick, "The susceptibility of various UK aggregates to alkali-silica reaction", Ph.D. thesis, Aston University, Birmingham, UK, 1993.

[44] M. Kawamura, K. Takeuchi, A. Sugiyama, "Mechanisms of expansion of mortars containing reactive aggregates in $\mathrm{NaCl}$ solution", Cement Concr. Res., vol. 24, no. 4, pp.621-632, 1994.

[45] M. Kawamura and K. Takeuchi, "Alkali-silica and pore solution composition in mortars in sea water", Cement Concr. Res., vol. 26, no. 12, pp.1809-1819, Dec. 1996

[46] R. G. Sibbick and C. L. Page, "Effects of sodium chloride on the alkali-silica reaction in hardened concretes", in Proceedings of the 10th International Conference on AAR, Melbourne, Australia, 1996, pp. 822-829.

[47] S. Diamond, "Alkali reactions in concrete-pore solution effects", in Proceedings of the 6th International Conference on AAR, Copenhagen, Denmark, Steen Rostam, 1983, pp. 155-167.

[48] M. Kawamura and M. Igarashi, "Characteristics of ASR in presence of sodium and calcium chloride", Cement Concr. Res., vol. 20, no. 5, pp.757-766, Sept. 1990.

[49] M.-A. Be'rube' and J. Frenette, "Testing concrete for AAR in $\mathrm{NaOH}$ and $\mathrm{NaCl}$ solutions at $38{ }^{\circ} \mathrm{C}$ and $80{ }^{\circ} \mathrm{C} "$, Cement Concr. Comp., vol. 16, no. 3, pp.189-198, 1994.

[50] J. Duchesne and M.-A. Be'rube', "Effect of deicing salt and sea water on ASR: new considerations based on experimental data" in Proceedings of the 10th International Conference on AAR, Melbourne, Australia, 1996, pp. 19-23.

[51] J. M. Vernon and W. G. Dubberke, "A different perspective for investigation of Portland cement concrete pavement deterioration", Transport. Res. Rec., vol. 1525, pp.91-96, 1996.

[52] M. Prezzi, P. J. M. Monteiro, and G. Sposito, "Alkali-silica reaction; Part 2: the effect of chemical additives", ACI Mat. J., vol. 95, no. 1, pp. 3-10, Jan. 1998

[53] K. E. Kurtis and P. J. M. Monteiro, "Chemical additives to control expansion of alkali-silica reaction gel: proposed mechanisms of control", J. Mat. Sci., vol. 38, no. 9, pp. 2027-2036, May 2003.

[54] X. Shi, "Impact of Airport Pavement Deicing Products on Aircraft and Airfield Infrastructure", ACRP Synthesis 6, Final Report. Airport Cooperative Research Program, Transportation Research Board, National Academies, Washington, D.C. April 2008.

[55] P. R. Rangaraju, K. R. Sompura, J. Olek, S. Diamond and J. Lovell, "Potential for development of alkali-silica reaction in presence of airfield deicing chemicals", in Proceedings of the 8th International Conference on Concrete Pavements, Colorado Springs, Aug. 1418, 2005.

[56] P. R. Rangaraju, K. R. Sompura and J. Olek, "Investigation into potential of alkali-acetate based deicers in causing alkali-silica reaction", in Compendium of Papers CD for the Transportation Research Board 85th Annual Meeting, Washington, D.C. Jan. 2006.

[57] P. R. Rangaraju and J. Desai, "Effectiveness of selected SCMs in mitigating ASR in presence of potassium acetate deicer solution", in Compendium of Papers CD for the Transportation Research Board 85th Annual Meeting, Washington, D.C. Jan. 2006.

[58] P. R. Rangaraju and J. Olek, "Potential for Acceleration of ASR in the Presence of Pavement Deicing Chemicals", Innovative Pavement Research Foundation, Final Report IPFR-01-G-002-039, Airport Concrete Pavement Technology Program, Skokie, IL; March 2007.
[59] P. R. Rangaraju, "Influence of airfield pavement deicing and antiicing chemicals on durability of concrete", in Proceedings 2007 FAA Worldwide Airport Technology Transfer Conference, Atlantic City, New Jersey, USA. April 2007.

[60] K. J. Folliard, M. D. A. Thomas and K. E. Kurtis, Guidelines for the Use of Lithium to Mitigate or Prevent ASR. FHWA Final Report FHWA-RD-03-047, July 2003.

[61] P. R. Rangaraju, K. Sompura, J. Desai and J. Olek, "Potential of potassium acetate deicer to induce ASR in concrete, and its mitigation", in Proceedings of Airfield and Highway Pavements 2006 Specialty Conference, I. L. Al-Qadi, Ed, 2006, pp.683-694.

[62] P. R. Rangaraju, "Mitigation of ASR in Presence of Pavement Deicing Chemicals", Innovative Pavement Research Foundation Final Report IPRF-01-G-002-04-8, April 2007.

[63] Federal Highway Administration (FHWA). Manual of Practice for Effective Anti-icing Program: A Guide for Highway Winter Maintenance Personnel. Report No. FHWA-RD-95-202. McLean, Va. 1996.

[64] W. C. Besselievre, "Deicing Chemical Rates on Open-Graded Pavements. Snow Removal and Ice Control Research", TRB Special Report 185. Transportation Research Board, Washington, DC., 1979.

[65] P. S. Kandhal and R.B. Mallick, "Open-Graded Friction Course: State of the Practice", Transportation Research Circular. Number E-C005, Dec. 1998.

[66] G. V. Heystraeten and R. Diericx, "A rapid and effective de-icing agent for open- graded road surfacings", in Proceedings of the XIth PIARC International Winter Road Congress, Sapporo, Japan, 2002.

[67] H. Iwata, T. Watanabe, and T. Saito, "Study on the performance of porous asphalt pavement in winter road surface conditions", in Proceedings of the XIth PIARC International Winter Road Congress, Sapporo, Japan, 2002.

[68] G. W. Flintsch, "Assessment of the performance of several roadway mixes under rain, snow, and winter maintenance activities", Final Report No. VTRC 04-CR18., Virginia Transportation Research Council. Charlottesville, VA., Feb. 2004

[69] F. C. Martinez, "Evaluation of Deicer Applications on OpenGraded Pavements", Final Report, SPR 616, Oregon Department of Transportation, 2006.

[70] G. Doré, J.-M. Konrad, and M. Roy, "Role of deicing salt in pavement deterioration by frost action", Transport. Res. Rec., vol. 1596, pp.70-75, 1997.

[71] Y. Hassan, A. O. Abd El Halim, A. G. Razaqpur and M. Farha, "Laboratory investigation of effect of deicing chemicals on airfield asphalt concrete pavements materials", in Proceedings 2 nd International Conference on Engineering Materials, San Jose, California, Aug. 16-19, 2001, vol. I, pp. 299-308.

[72] Y. Hassan, A. O. Abd El Halim, A. G. Razaqpur, W. Bekheet and M. Farha, "Effects of runway deicers on pavement materials and mixes: comparison with road salt", J. Transp. Engrg. vol. 128, no. 4, pp. 385-391, July/Aug 2002.

[73] J. R. McCutchon, A. P. Joseph, and J. Van Valkenburg, "Assessment of the effect of urea deicing solution on asphaltic concrete pavements". Project No. 999821, Public Works and Government Services Canada. Hull, Canada, 1992.

[74] M. H. Farha, Y. Hassan, A. O. Abd El Halim, A. G. Razaqpur, A. El-Desouky, and A. Mostafa, "Effects of new deicing alternatives on airfield asphalt concrete pavements" presented at the 2002 Federal Aviation Administration Technology Transfer Conference, January 2002.

[75] F. Nilsson, "Durability problems on Nordic airfields-the influence of deicing agents on asphalt concrete", in Proceedings of the XXIInd PIARC World Road Congress, 2003.

[76] Seminar on the Effects of De-Icing Chemicals on Asphalt, Helsinki, Finland, March 2006.

[77] T. Pan, X. He, and X. Shi, "Laboratory investigation of acetatebased deicing/anti-icing agents deteriorating airfield asphalt concrete", J. Assoc. Asphalt Pav. Tech., vol. 77, 2008, in press.

[78] Advanced Asphalt Technologies, LLC. "Phase II plans with summary of phase I results", Interim Report, Airfield Asphalt Pavement Technology Program Project 05-03: Effect of Deicing Chemicals on HMA Airfield Pavements, May 2, 2007.

[79] V. Alatyppö, Conclusions-Finnish Deicing Project, Helsinki University of Technology, Laboratory of Highway Engineering, 2005. 
[80] J. Valtonen, "JAPA: the Finnish de-icing project", presentation at the Seminar on the Effects of De-Icing Chemicals on Asphalt, Helsinki, Finland, March 14, 2006.
[81] V. Alatyppö and J. Valtonen, "Experiences on the effects of deicing chemicals on bituminous airfield runways in Finland", in Proceedings of the 2007 FAA Worldwide Airport Technology Transfer Conference, Atlantic City, New Jersey, April 16-18, 2007.

(C) Shi et al.; Licensee Bentham Open.

This is an open access article licensed under the terms of the Creative Commons Attribution Non-Commercial License (http://creativecommons.org/licenses/by$\mathrm{nc} / 3.0 /$ ) which permits unrestricted, non-commercial use, distribution and reproduction in any medium, provided the work is properly cited. 